\title{
CHALLENGES AND OPPORTUNITIES IN THE FIELD OF BUSINESS AND MANAGEMENT
}

\author{
Sherry Samuel Oommen*
}

\begin{abstract}
In this essay, the writer has placed his personal views regarding the subject and invites comments regarding the gravity of the situation. The writer seeks to highlight the point that in a capitalist economy, unless the forces of terror are destroyed, a nation cannot progress. The writer also speaks about the impending dangers of terror and the challenges it openly.
\end{abstract}

\section{Introduction}

It is a well known or rather an established fact in the history of the Israel that after the death of Lord Jesus Christ, the hatred between the Jews and Gentiles grew. Many of the Apostles of the Lord Jesus Christ had tried their level best to ensure an early settlement to the prevalent hostility. As is evident in history, the existing hostility was an occasion, any enemy of an Israelite rejoiced about.

It was then, that one of the mediators namely, Apostle Paul, who wrote to the Gentiles (who were considered as slaves) in Israel, proclaiming the spiritual inheritance that they possessed. For Apostle Paul spoke:

* Sherry Oommen has completed his graduation in commerce from Bangalore University in May 2001. He is currently pursuing Chartered Accountancy and is working with Arthur Andersen, Bangalore. He may be contacted at sherry.s.oommen@in.andersen.com. 
"For you have not received a spirit of slavery leading to fear again, but you have received a spirit of adoption as sons by which we cry out, "Abba Father!" (Romanis 8:15).

Apostle Paul had spoken these words primarily to emphasise the spiritual inheritance the Gentiles possessed in Israel. He had used his rhetoric ability in speech to convey to the Gentiles, the power of a "SON" the Gentiles possessed and thus, the Gentiles were exhorted to be freed from the bonds of slavery. Why did Apostle Paul harp on the words "a spirit of adoption as sons"? The only reason that I personally perceive, being the simple truth that unless the spirit of brotherhood prevails it is impossible for any civilisation to move ahead, leave alone a business.

Well, a question now arises, "Why all this spiritual talk, when the question of "slivvery" in the current scenario does not arise?" Let's ponder for a moment, "Are we in the twenty=first century bound by any form of slavery?" Or more simply, "Has any power, principality or dominion enslaving the entire mankind?

A lot of scholars around the world would have ridiculed the thought of the entire world being "enslaved" by a principality, power or a dominion, until a catastrophe occurred on September 11, 2001.

Well, was September 11, 2001, a mere coincidence? Or was it a game of destiny/fortitude? If the events that occurred on September 11, 2001 were a mere coincidence, then why talk about a world that is controlled of a power, namely, TERROR?

\section{September 11, 2001}

\section{WHAT EXACTLY HAPPENED ON SEPTEMBER 11, 2001?}

In short, the whole was struck by a wave of terror leashed. Sadly, the victims of such a dastardly act turned out to be innocent. A brief chronology of the beginning of terror, on the said day. was as follows:

$8.45 \mathrm{am}$ (all times are EDT): A hijacked passenger jet, American Airlines Flight 11 out of Boston, Massachusetts, crashes into the north tower of the World Trade Centre (WTC), tearing a gaping hole in the building and setting it afire.

$9.03 \mathrm{am}$ A second hijacked airliner, United Airlines, Flight 175 from Boston, crashes into the south tower of the WTC and explodes. Both buildings are burning.

9:43 am American Airlines Flight 77, crashes into the Pentagon, sending up a huge plume of smoke 
10:10 am United Airlines Flight 93, also hijacked crashes into Somerset Country, Pennsylvania, south-east of Pittsburgh.

September 11, 2001, a day in which a holocaust of four planes crash occurred in less than two hours. Sadly, not a Spielberg movie as many would have loved it to be!

Now, there arises a question, "whether the four plane crashes, were coincidental?" If they were not, was an action of this intensity and damage expected to be leashed by the proponents of terror? If it was expected, then why was this dastardly act permitted to happen? I am unable to find an answer to this question, yet I find myself in a quagmire of further questions.

At hindsight, the existence of the master craftsman Osama Bin Laden, and his possible "pranks" were well known to World leaders. Then, why was this prankster, permitted to play his pranks? A few believe that Bin Laden has survived so long, primarily on account of a political-military strategy, a strategy that is reprehensible. The current focus of the world fury, Osama Bin Laden was a beneficiary of the US covert war in Afghanistan. Sadly, against American expectations, Bin Laden was named as a suspect in the bombings of the two US embassies in East Africa.

Further, can the incident on September 11, 2001 be termed as part of a wellschemed piece of literature? I doubt. If the world knew, the impending dangers of TERROR, why was TERROR not handled well? I personally feel that by adding religion to the forces of destruction and terror, the perpetration of terror has been veiled. To substantiate further, the attacks of the Jammu and Kashmir Legislative Assembly and the Indian Parliament, have further exposed the depraved state of mind, of the perpetrators of terror.

A question that now needs to be considered, given that the entire mankind is plagued with the menace of terror, is whether the business community can help mankind in this fight against terror. It would be wrong from any businessman to presume that this fight against terror, as the lone battle of Mr. George Bush or Mr. Vajpayee or for that matter, even President Musharuff (if he considered the fight against terror as a WAR!).

The impact of the September $11^{\text {th }}$ attacks, the attack on the Jammu and Kashmir Legislative Assembly and the Indian Parliament has affected businesses around the world. The need of the hour is, given the prevalent uncertainty, can a business house survive this pestilence of time? I personally believe that a door of opportunity has been opened, with a lot to be explored. 


\section{Terror-Its effect on business and the way forward}

In a study conducted by Pricewaterhouse Coopers ("PWC"), regarding the impact of the September 11, 2001 incidents, Frank Brown, the global leader of Assurance and Business Advisory Services observed that "Optimism about the economy had eroded significantly prior to September 11, and worsened even further in the aftermath of the attacks".

In the said study that was conducted, it was observed that for the quarter ending September 30, 2001, the amount spent by business houses for research and development dropped by $20 \%$ (off 17 points from the prior quarter), new product or service introduction fell by $38 \%$ (off 15 points) and facilities expansion dropped by $15 \%$ (off 13 points from the prior quarter), during the said quarter.

Further, to gauge the business mood after the September 11 attacks, only 23\% of the entire business community had an optimistic view. In contrast, $55 \%$ of the entire business community felt that the road ahead of them was tough and thus the chances of survival were grim.

To substantiate further, the revenue growth for the quarter ending September 30,2001 was $6.4 \%$ (a fall of 78 percent overall). It is evident, that the forces of terror have set their footprints even on businesses and this cannot be denied.

Thus, every businessman is now faced with a challenge. Given the existence of a challenge, what is the opportunity that a businessman can explore to his gain?

Well as the saying going "unless the strong man is bound, it is impossible to build or enter the house". Thus, in a world that is stricken with terror, unless the fortresses of terror are reduced to dust, the possibility of a civilisation surviving, leave alone a business surviving, is minimal.

If poverty and fear of exploitation are the cause for the growth of terrorists, then businessmen should sacrifice their molives of profit and seek for developing the quality of life of every individual. It may be noted and as quoted by Joan Robinson, a senior economist that "the misery of being exploited by the capitalist is nothing compared to the misery of not being exploited at all". Well, if poverty and misery is an issue, then it is high time that business houses, pushed their motives of profit to the back seat and instead sought after developing the less privileged States.

Further, every business house must play an important role in restoring the harmony among the people of a nation. For instance, mobilising efforts towards 
creating unity amongst the people of a nation could go a long way in preserving the integrity of any nation. Thus, it is through brotherhood that unity can be maintained.

"A house that is divided shall fall" and this dictum holds well. if the forces of terror can divide a house, there is no doubt that the house will fall. Thus, to keep the entire nation from being divided by the forces of terror, business houses must seek to preserve the unity of the nation. Else, a business conglomerate or a nation could become history!!!!

I believe as foretold by Prophet Isaiah,

"No more, shall a nation rise up against another,

Or a man against his brother" shall come to pass, provided there is a combined effort directed towards driving away the forces of terror from the earth.

Well, once the powers of terror have been bound, "goodness and mercy" shall follow ever after. Once the battle is won, the victors cry will be:

"O terror, where is your string

$O$ terror, where is your victory

For the forces of peace and brotherly love have overcome. Thanks to our united effort" 